Pediat. Res. 6 : 552-562 (1972)

Cyclic AMP

1,25-dihydroxycholecalciferol

25-hydroxycholecalciferol

parathyroid hormone

rickets

vitamin D

\title{
Vitamin D-Dependent Rickets: Actions of Parathyroid Hormone and 25-Hydroxycholecalciferol
}

\author{
John F. Rosen ${ }^{[59]}$ and Laurence Finberg \\ Department of Pediatrics, Montefiore Hospital and Medical Center and The Albert Einstein College of Medicine, Bronx, New York, USA
}

\section{Extract}

During active rickets, the increase in $3^{\prime}, 5^{\prime}$-adenosine monophosphate $\left(3^{\prime}, 5^{\prime}\right.$-AMP) excretion after infusion of parathyroid hormone (PTH) can be claimed as a demonstration of PTH responsiveness, at least as far as the kidney is concerned (Table II). In patients with vitamin D-dependent rickets, following 25-HCG therapy, the basal excretion ratios of nanomoles $3^{\prime}, 5^{\prime}$-AMP/milligrams creatinine fall within the normal range, and, although the basal ratios of milligrams phosphate/milligrams creatinine excretion decrease to normal (Tables III, IV, and V), a phosphaturic response to PTH is still not evident. The high basal ratios of nanomoles $3^{\prime}, 5^{\prime}$-AMP/ milligrams creatinine and milligrams phosphate/milligrams creatinine suggest underlying hyperparathyroidism during a phase of this syndrome marked by hypocalcemia and hyperaminoaciduria. During 2-day PTH challenges, while rickets was active, the peak increases in serum calcium above base line were 1.92, 1.80, and $1.86 \mathrm{mg} / 100 \mathrm{ml}$. After treatment with 25-hydroxycholecalciferol $(25-\mathrm{HCG})$, no further significant increases in serum calcium above base line could be elicited (Tables VI, VII, VIII). It would seem, therefore, that, while these patients were untreated, small but sufficient amounts of $25-\mathrm{HCG}$ or another metabolite of vitamin $\mathrm{D}$ were available to permit the calcium-mobilizing action of PTH on bone. The observed hypocalcemia in vitamin D-dependent rickets, then, is most likely secondary to a defect in gastrointestinal absorption. Mineral balance studies during active rickets revealed an absorptive defect for calcium, phosphorus, and magnesium - a defect completely reversible after $25-\mathrm{HCC}$ treatment.

\section{Speculation}

We suggest that the small intestine represents the prime target organ site for impaired vitamin $\mathrm{D}$ action in this disease by differential failure in the biologic formation of 1,25-dihydroxycholecalciferol from 25-HCC. Similarly, we postulate that a variable hydroxylating deficiency may be present in the transformation of vitamin $\mathrm{D}_{3}$ to $25-\mathrm{HCC}$. Genetic heterogeneity, therefore, may ultimately explain common responses in these three patients to contrasting doses of dihydrotachysterol (DHT) and $25-\mathrm{HCC}$.

\section{Introduction}

Vitamin D-dependent rickets is characterized by hypocalcemia, hyperaminoaciduria, and relatively mild growth failure $[4,13-15,19,29,43]$. Because 10-100 times the usual daily requirement for vitamin $\mathrm{D}$ is necessary to correct this disorder, speculations concern- 
ing its pathogenesis have focused mainly upon an abnormality in vitamin $\mathrm{D}$ metabolism.

The present study was designed to evaluate, before and after 25-HCG treatment, PTH action at three target organ sites: kidney, bone, and gastrointestinal tract. By so doing, perhaps, a dissociation between the effectiveness or defectiveness of action of PTH or vitamin $\mathrm{D}$, or both, could be discerned. The data, in the active phase of the disease, demonstrated: (1) PTH responsiveness for the kidney, to an extent which suggested underlying hyperparathyroidism; (2) effective PTH action on bone where the presence of vitamin D in its biologically active form, probably 25-HCG [34, 45], is necessary for the expression of PTH action; and (3) impaired gastrointestinal absorption of calcium, phosphorus, and magnesium. At this site, 1,25-dihydroxycholecalciferol, generated in kidney tissue from 25-HCC, is thought to be the metabolite responsible for mineral absorption from the intestinal lumen [25, 33, 34]. Current evidence suggests that orally administered DHT follows pathways similar to those of the natural vitamin $[11,18]$.

Studies repeated before and after 25-HCC therapy, and after contrasting doses of DHT and 25-HCC, may focus attention on deficient formation of 1,25-dihy. droxycholecalciferol and on the possibility of genetic heterogeneity in this entity (entities).

\section{Patients}

Three patients, a 4.5-year-old Negro boy (Patient 2), and two Puerto Rican brothers, 12 and 14 years of age, qualified for these studies on the basis of growth failure, hypocalcemia, low or normal serum phosphate levels, elevated serum alkaline phosphate levels, hyperaminoaciduria [55], and x-ray evidence of rickets, in the face of normal dietary intake of calories, protein, and vitamin $\mathrm{D}$. None of them, therefore, had vitamin D-deficient rickets or familial hypophosphatemia (vitamin D-resistant rickets). Thus, all patients qualified for the entity (entities) currently designated as vitamin D-dependent rickets. Patient 2 responded well to DHT, whereas the two brothers did not respond at any time to very large doses of DHT. Similarly, both brothers required larger doses of 25-HCC [53] for complete healing than did patient 2. None of these patients responded to less than $500 \mathrm{IU}$ of $25-\mathrm{HCC} / 24 \mathrm{hr}$; and, as has been reported by others [4], the absolute range for therapeutic response to vitamin $\mathrm{D}(25-\mathrm{HCC}$ in these reported patients) was extremely narrow, particularly in patient 2. (See Table I and Case Reports.)

\section{Case Reports}

Patient 1. SR, a 12-year-old boy of Puerto Rican origin was admitted to the Pediatric Clinical Research Center in November, 1969, with the chief complaint of pain and deformity in the lower extremities for 2 years. He had a history of similar symptoms at age 1.5 years and some improvement after receiving "vitamins," but without ever having become normal. Dietary history was adequate. On physical examination, shortness of stature was evident, but his appearance reflected good nutrition. Moderate rachitic deformities of the extremities were present.

Routine laboratory findings were normal; the chemical analyses on admission are listed in Table I, and the laboratory course is charted below.

$S R$ did not respond to a 1-month trial of $1000 \mathrm{IU}$ of

\begin{tabular}{cccc}
\hline Date & $\begin{array}{c}\text { Calcium, } \\
\mathrm{mg} / 100 \mathrm{ml}\end{array}$ & $\begin{array}{c}\text { Phosphorus, } \\
\mathrm{mg} / 100 \mathrm{ml}\end{array}$ & $\begin{array}{c}\text { Alkaline } \\
\text { phosphatase, } \\
\text { Bessey-Lowry } \\
\text { units }\end{array}$ \\
\hline $11 / 28 / 69$ & 6.9 & 4.3 & 24 \\
$12 / 8 / 69$ & 5.0 & 4.4 & 18 \\
$1 / 30 / 70$ & 7.9 & 5.5 & 15 \\
$6 / 8 / 70$ & 7.5 & 3.6 & 17 \\
$9 / 21 / 70$ & 9.7 & 3.8 & 17 \\
$1 / 12 / 71$ & 9.5 & 6.2 & 6 \\
\hline
\end{tabular}

Table I. Summary of initial clinical and biochemical data for patients with active rickets ${ }^{1}$

\begin{tabular}{|c|c|c|c|c|c|c|c|c|c|}
\hline Patient & $\begin{array}{c}\text { Age at } \\
\text { diagnosis, } \\
\text { yr }\end{array}$ & Presenting symptom & $\begin{array}{c}\text { Enamel } \\
\text { hypoplasia }\end{array}$ & $\begin{array}{c}\text { Total } \\
\text { serum } \\
\text { calcium, } \\
\mathrm{mg} / 100 \mathrm{ml}\end{array}$ & $\begin{array}{l}\text { Serum } \\
\text { inorganic } \\
\text { phosphorus, } \\
\mathrm{mg} / 100 \mathrm{ml}\end{array}$ & $\begin{array}{l}\text { Serum } \\
\text { magnesium, } \\
\mathrm{mEq} / \mathrm{liter}\end{array}$ & $\begin{array}{l}\text { Serum alkaline } \\
\text { phosphatase, } \\
\text { Bessey-Lowry } \\
\text { units }\end{array}$ & $\begin{array}{l}\text { Hyper- } \\
\text { amino- } \\
\text { aciduria }\end{array}$ & $\begin{array}{c}\text { Radiologic } \\
\text { diagnosis }\end{array}$ \\
\hline$S R^{2}$ & 14 & Short stature & - & 6.90 & 4.30 & 1.90 & 24 & + & Active rickets \\
\hline$J M^{3}$ & 4.5 & Short stature & + & 7.80 & 4.30 & 2.00 & 19 & + & Active rickets \\
\hline$A R^{2}$ & 12 & Short stature & - & 7.20 & 4.80 & 1.85 & 22 & + & Active rickets \\
\hline
\end{tabular}

1 Normal values: total serum calcium, 9-11 mg/100 ml; serum inorganic phosphorus, 4-6 mg/100 ml; serum magnesium, $1.7-2.3 \mathrm{mEq}$ liter; serum alkaline phosphatase, 3-7 Bessey-Lowry units.

${ }^{2}$ Male Puerto Rican siblings.

${ }^{3}$ Negro male. 
25-HCC/24 hr, nor did he respond to $1.4 \mathrm{mg}$ of $\mathrm{DHT} / 24$ hr for 6 months. In July, 1970, he began to receive increasing doses of 25-HCC, beginning with $3000 \mathrm{IU} / 24 \mathrm{hr}$. Weekly increments of $1000 \mathrm{IU} / 24 \mathrm{hr}$ were given until a dose of $5000 \mathrm{IU} / 24 \mathrm{hr}$ was reached. By late September, 1970, the level of calcium in serum became normal, and by December, 1970, his x-rays showed good, nearly complete healing of rickets, while the level of alkaline phosphatase in serum also became normal.

Patient 2. JM, a 4.5-year-old Negro boy, was admitted to the Pediatric Clinical Research Center in August, 1969. The family history revealed several close relatives with shortness of stature, but without any known diagnosis of metabolic bone disease. The mother's serum calcium, phosphorus, and alkaline phosphatase were normal. The patient's medical history was unremarkable until he was brought for examination because of an awkward gait of several months' duration. Dietary history was adequate with regard to fortified milk intake all of his life and vitamin supplements during the 1st year of life.

On physical examination, his height was below the 3rd percentile, and weight was at the 25th percentile. Enamel hypoplasia was observed. A rachitic rosary was present. Mild bowing of the femora and tibiae and a Marfan sign were noted. An umbilical hernia persisted.

Routine laboratory tests were normal; the initial serum analyses are listed in Table I.

The initial diagnostic impression was of familial hypophosphatemia, although the low serum calcium was unexplained. $J M$ was treated with $2 \mathrm{mg} \mathrm{DHT} / 24 \mathrm{hr}$, and, as a result, serum calcium returned to normal $(9.5$ $\mathrm{mg} / 100 \mathrm{ml}$ ), serum phosphate rose to $5.8 \mathrm{mg} / 100 \mathrm{ml}$, and alkaline phosphatase fell to 10 Bessey-Lowry units. $\mathrm{X}$-rays provided evidence of healing, and the DHT dosage was reduced to $0.5 \mathrm{mg} / 24 \mathrm{hr}$. This combination of events (normal to high serum phosphate on therapy and the finding of hyperaminoaciduria) rendered the diagnosis of familial hypophosphatemia untenable even though the therapy was succeeding.

After DHT was discontinued for 2 months, $J M$ was readmitted for the special studies reported below. Upon discharge, he received $250 \mathrm{IU}$ 25-HCC/24 hr. Dosage was increased by increments of $250 \mathrm{IU}$ every 3 weeks until a dose of $1000 \mathrm{IU} / 24 \mathrm{hr}$ was reached. Although this dose resulted in complete chemical and $\mathrm{x}$-ray healing of the rickets, it is possible that a longer period of treatment with $500 \mathrm{IU}$, or less, of $25-\mathrm{HCC}$ might have achieved the same result. $\mathrm{He}$ has been maintained on this dosage for 2 years without relapse.

Patient 3. AR, the 14-year-old brother of Patient 1 was also admitted to the Pediatric Clinical Research Center in November, 1969. The history and physical findings were essentially the same as those for his younger brother.

Routine laboratory findings were negative and other data are listed below and in Table I.

A I-month trial of 400-2000 IU 25-HCC/24 hr had no effect on the x-rays, serum chemical analyses, or symptoms of $A R$. Then, on December 15, 1969, he was given $2 \mathrm{mg} \mathrm{DHT} / 24 \mathrm{hr}$; dosage was increased to 3 $\mathrm{mg} / 24 \mathrm{hr}$ on January 15,1970 , and to $4 \mathrm{mg} / 24 \mathrm{hr}$ on February 15, 1970, and the last dosage was maintained until July 20, 1970. At this time, symptoms persisted, $\mathrm{x}$-rays continued to show activity, and serum values were: calcium, $6.8 \mathrm{mg} / 100 \mathrm{ml}$; phosphorus, $4.0 \mathrm{mg} / 100$ $\mathrm{ml}$; and alkaline phosphatase, 27 Bessey-Lowry units. No toxicity had been manifest. $A R$ was then placed on increasing doses of 25-HCC until $5000 \mathrm{IU} / 24 \mathrm{hr}$ was reached. The first improvements in serum analyses were noted in late September, 1970, and, by December, 1970, x-rays showed complete healing.

\begin{tabular}{rccc}
\hline Date & $\begin{array}{c}\text { Calcium, } \\
\mathrm{mg} / 100 \mathrm{ml}\end{array}$ & $\begin{array}{c}\text { Phosphorus, } \\
\mathrm{mg} / 100 \mathrm{ml}\end{array}$ & $\begin{array}{c}\text { Alkaline } \\
\text { phosphatase, } \\
\text { Bessey-Lowry } \\
\text { units }\end{array}$ \\
\hline $7 / 20 / 70$ & 6.8 & 4.0 & 27 \\
$9 / 22 / 70$ & 8.1 & 2.5 & 23 \\
$10 / 26 / 70$ & 9.6 & 6.0 & 12 \\
$11 / 23 / 70$ & 9.1 & 5.3 & 9.3 \\
$12 / 14 / 70$ & 9.2 & 5.3 & 8.8 \\
$2 / 22 / 71$ & 9.4 & 4.9 & 6.6 \\
\hline
\end{tabular}

Methods

\section{Routine Tests}

Prior to the special studies noted below, the following tests were performed routinely on each patient.

Serum: sodium, potassium, carbon dioxide, chloride, urea nitrogen, antirachitic activity [46, 54], albumin, globulin, bilirubin, serum glutamic oxaloacetic transaminase/serum glutamic pyruvic transaminase, cholesterol, triglycerides, lipoproteins, oral glucose tolerance test, oral iron tolerance test [38], and concentration of vitamin $\mathrm{B}_{12}$.

Urine: creatinine clearance and excretion of $\mathrm{D}$-xylose [6].

Stool: fat excretion [47].

Radiology: small intestine. 


\section{Special Studies}

$3^{\prime}, 5^{\prime}$-AMP Excretion. While the patient was on a normal mineral intake and was receiving $400 \mathrm{U}$ vi$\operatorname{tamin} \mathrm{D} / 24 \mathrm{hr}$, the hourly excretion of $3^{\prime}, 5^{\prime}$-AMP was determined from 8:00 AM until 12 noon. On the 2nd day, however, at 9:00 AM, $150 \mathrm{U}$ of PTH [52] in $25 \mathrm{ml}$ isotonic saline was infused intravenously. This infusion lasted about $10 \mathrm{~min}$. Specimens of urine were collected hourly and measured, and aliquots were immediately frozen and stored at $-20^{\circ}$ until $3^{\prime}, 5^{\prime}$-AMP could be determined. Base line (control), interval, and total test time excretion of $3^{\prime}, 5^{\prime}$-AMP were measured according to the technique of Chase et al. [9] which is based upon the enzymatic conversion of the nucleotide to adenosine triphosphate and detection of the latter by means of an adenosine triphosphate- ${ }^{32} \mathrm{P}_{1}$ exchange. About $200 \mathrm{ml}$ water $/ \mathrm{hr}$ were given by mouth from 6 AM to noon.

Phosphorus/Creatinine Ratio. The hourly excretion of milligrams phosphate/milligrams creatinine was determined by the same protocol as that used for $3^{\prime}, 5^{\prime}$ AMP.

$\Delta$ Serum Calcium. While the patient was on a normal mineral intake and was receiving $400 \mathrm{U}$ vitamin $\mathrm{D} / 24 \mathrm{hr}, 150 \mathrm{U}$ PTH were injected intramuscularly every $6 \mathrm{hr}$ for 2 days. Serum samples were obtained every $3 \mathrm{hr}$ for determination of calcium, and the $\Delta$ serum calcium (height response) was measured during this 2-day period.

General Balance Techniques. Standard mineral balance techniques were performed in the Pediatric Clinical Research Center of Montefiore Hospital and Medical Center. Subjects were offered a diet which was constant in calories, nitrogen, and mineral content. Composition of the diet was analyzed in duplicate. All food refused was weighed and subtracted from the daily intake. Daily venous blood specimens and 24-hr urine specimens were collected. Stools were separated at the end of each period with carmine marker and the pooled specimen for the balance study of 10 days, with at least a 4-day period of preequilibration, was subsequently analyzed. Oral chromic oxide, $120 \mathrm{mg} / 24 \mathrm{hr}$, served as a daily internal reference standard. The following methods were used for analysis: calcium, MacIntyre [27]; magnesium, Alcock et al. [1]; phosphorus, Fiske and Subbarow [16]; nitrogen, micro-Kjeldahl [22]; creatinine, Clark and Thompson [10]; alkaline phosphatase, Bessey et al. [7].

All studies were repeated during complete clinical, chemical, and x-ray remission while patients were receiving 1000 or 5000 IU 25 -HCC daily.

\section{Results}

\section{3',5'-AMP Excretion}

During active rickets, basal excretion values of $3^{\prime}, 5^{\prime}$-AMP, expressed as the ratio of nanomoles $3^{\prime}, 5^{\prime}$ AMP/milligrams creatinine, were $5.85,6.10$, and 5.62 for the 3 patients. These values were higher than normal ones previously reported [5, 9]. Increase in $3^{\prime}, 5^{\prime}$ AMP excretion, after infusion of PTH, was rapid in onset and almost complete in $\mathrm{l} \mathrm{hr}$ (Table II). The peak values of 82,92 , and 99 represent exaggerated responses $[5,9]$. Fluctuations in the high basal ratios of milligrams phosphate/milligrams creatinine excretion [9] obscured a phosphaturic response to PTH, if indeed, this did occur (Table III). Thus, the increased excretion of $3^{\prime}, 5^{\prime}$-AMP after PTH infusion can be interpreted as a demonstration of $\mathrm{PTH}$ responsiveness of the kidney in this disease $[5,9,23,30,41,44]$.

After patients were treated with 25-HCC, the basal excretion ratios of nanomoles $3^{\prime}, 5^{\prime}$-AMP/milligrams creatinine $(3.19,3.97,3.63)$ fell within the normal range $[5,9]$ and the increase in nanomoles $3^{\prime}, 5^{\prime}$-AMP/ milligrams creatinine excretion after PTH infusion was no longer as exaggerated as before (Table IV).

Table II. Basal excretion in urine of nanomoles $3^{\prime}, 5^{\prime}$-AMP/milligrams creatinine by patients with active rickets ${ }^{1}$

\begin{tabular}{|c|c|c|c|c|c|c|}
\hline \multirow{2}{*}{ Time, hr } & \multicolumn{2}{|c|}{ Patient 1 (SR) } & \multicolumn{2}{|c|}{ Patient $2(J M)$} & \multicolumn{2}{|c|}{ Patient $3(A R)$} \\
\hline & Control period & PTH challenge & Control period & PTH challenge & Control period & PTH challenge \\
\hline 1 & 7.00 & 4.25 & 7.04 & 3.65 & 5.38 & 6.25 \\
\hline 2 & 6.23 & $82.0^{2}$ & 7.26 & $92.0^{2}$ & 6.25 & $99.0^{2}$ \\
\hline 3 & 5.85 & 9.65 & 4.35 & 12.65 & 3.92 & 10.15 \\
\hline \multirow[t]{2}{*}{4} & 4.32 & 6.08 & 5.85 & 5.52 & 7.16 & 4.19 \\
\hline & $5.85 \pm 0.60^{3}$ & & $6.10 \pm 0.70$ & & $5.62 \pm 0.69$ & \\
\hline
\end{tabular}

${ }^{1}$ For parathyroid hormone (PTH) challenge, PTH was administered intravenously at hour $1.3^{\prime}, 5^{\prime}$-AMP $: 3^{\prime}, 5^{\prime}$-adenosine monophosphate.

${ }^{2}$ Peak of excretion.

${ }^{3}$ Mean \pm 1 SEM. 
Table III. Hourly excretion in urine of milligrams phosphate/milligrams creatinine by patients with active rickets ${ }^{1}$

\begin{tabular}{|c|c|c|c|c|c|c|}
\hline \multirow{2}{*}{$\underset{h \mathbf{r}}{\operatorname{Time}}$} & \multicolumn{2}{|c|}{ Patient 1} & \multicolumn{2}{|c|}{ Patient 2} & \multicolumn{2}{|c|}{ Patient 3} \\
\hline & Control period & PTH challenge & Control period & PTH challenge & Control period & PTH challenge \\
\hline I & 3.64 & 4.56 & 2.05 & 2.48 & 3.75 & 3.21 \\
\hline 2 & 4.00 & 3.94 & 4.48 & 3.48 & 4.09 & 1.67 \\
\hline 3 & 4.12 & $3.4 \mathrm{I}$ & 3.80 & 3.05 & 2.88 & 2.08 \\
\hline 4 & 3.92 & 4.25 & 1.69 & 3.44 & 3.55 & 1.98 \\
\hline & $3.92 \pm 0.08^{2}$ & $4.04 \pm 0.06$ & $3.00 \pm 0.67$ & $3.11 \pm 0.23$ & $3.56 \pm 0.25$ & $2.23 \pm 0.35$ \\
\hline
\end{tabular}

${ }^{1}$ For parathyroid hormone (PTH) challenge, PTH was administered intravenously at hour 1.

2 Mean \pm 1 SEM.

Table IV. Excretion in urine of nanomoles $3^{\prime}, 5^{\prime}$-AMP/milligrams creatinine by patients with healed rickets after 25 -hydroxycholecalciferol therapy ${ }^{1}$

\begin{tabular}{|c|c|c|c|c|c|c|}
\hline \multirow{2}{*}{ Time, hr } & \multicolumn{2}{|c|}{ Patient 1} & \multicolumn{2}{|c|}{ Patient 2} & \multicolumn{2}{|c|}{ Patient 3} \\
\hline & Control period & PTH challenge & Control period & PTH challenge & Control period & PTH challenge \\
\hline 1 & 2.50 & 3.85 & 3.25 & 4.39 & 2.89 & 4.01 \\
\hline 2 & 3.92 & $24.0^{2}$ & 4.16 & $19.0^{2}$ & 3.19 & $31.0^{2}$ \\
\hline 3 & 3.01 & $5.6 \mathrm{i}$ & 3.46 & 5.16 & 4.24 & 8.25 \\
\hline \multirow[t]{2}{*}{4} & 3.31 & 3.62 & 5.01 & 4.29 & 4.19 & 3.16 \\
\hline & $3.19 \pm 0.30$ & & $3.97 \pm 0.40$ & & $3.63 \pm 0.34$ & \\
\hline
\end{tabular}

${ }^{1}$ For parathyroid hormone (PTH) challenge, PTH was administered intravenously at hour $1.3^{\prime}, 5^{\prime}$-AMP: $3^{\prime}, 5^{\prime}$-adenosine monophosphate.

2 Peak of excretion.

${ }^{3}$ Mean \pm 1 sem.

The time course of peak excretion remained the same. When patients were treated, a phosphaturic response to PTH was still not evident (Table V) even though the basal ratios of milligrams phosphate/milligrams creatinine excretion decreased to normal limits. However, the appropriately increased excretion of $3^{\prime}, 5^{\prime}$ AMP after PTH infusion represents a more sensitive parameter of $\mathrm{PTH}$ action on the kidney $[5,9,23,30$, 41, 44].

\section{PTH Challenges}

The peak changes above base line in serum calcium during the 2-day PTH challenges, while rickets was active, were $1.92,1.80$, and $1.86 \mathrm{mg} / 100 \mathrm{ml}$. These increases of serum calcium above $1.50 \mathrm{mg} / 100 \mathrm{ml}$ are accurate and normal indications of the calcium-mobilizing action of $\mathrm{PTH}$ under these conditions [20, 21]. While patients were treated with 25-HCC, no further significant increases in serum calcium above base line could be elicited (Tables VI, VII, VIII) when no evidence of rickets could be demonstrated.

\section{Mineral Balance}

Complete mineral balance studies were performed on the 4.5-year-old patient (Patient 2, JM) and on one of the brothers with this syndrome, 14-year-old $A R$ (Patient 3). During the active phase of this disease, an absorptive defect was found which involves calcium, phosphorus, and magnesium. After patients were treated with 25-HCC and healing of rickets was complete, the absorption of these minerals was normal (Table IX).

\section{Discussion}

Refractoriness of PTH has been reported in this syndrome $[15,29]$. If this finding was confirmed at a target organ where it is established that PTH action is independent of the presence of vitamin $D[3,17]$, then it would appear increasingly difficult to separate the individual actions or to associate the joint actions of PTH and vitamin D. Indeed, a reliable indicator of target organ response of the kidney to exogenous PTH has been demonstrated, namely increased urinary excretion of $3^{\prime}, 5^{\prime}$-AMP.

The apparent dissociation between $3^{\prime}, 5^{\prime}$-AMP and phosphate excretion, in response to $\mathrm{PTH}$ challenge, is not unique to this study. Phosphaturic response may be inconstant, indistinguishable from diurnal variations, and frequently small [12]. On the other hand, the response manifested in $3^{\prime}, 5^{\prime}$-AMP excretion, dur- 
Table $V$. Hourly excretion in urine of milligrams phosphate/milligrams creatinine by patients with healed rickets after 25 -hydroxycholecalciferol therapy

\begin{tabular}{|c|c|c|c|c|c|c|}
\hline \multirow{2}{*}{$\begin{array}{c}\text { Time, } \\
\mathrm{hr}\end{array}$} & \multicolumn{2}{|c|}{ Patient 1} & \multicolumn{2}{|c|}{ Patient 2} & \multicolumn{2}{|c|}{ Palient 3} \\
\hline & Control period & PTH challenge & Control period & PTH challenge & Control period & PTH challenge \\
\hline 1 & 0.45 & 0.65 & 0.25 & 0.62 & 1.41 & 1.26 \\
\hline 2 & 0.85 & 0.79 & 0.85 & 0.95 & 0.98 & 1.30 \\
\hline 3 & 0.37 & 0.35 & 1.25 & 0.47 & 1.02 & 0.52 \\
\hline 4 & 0.66 & 0.58 & 0.69 & 1.28 & 0.38 & 0.69 \\
\hline & $0.58 \pm 0.1^{2}$ & $0.60 \pm 0.09$ & $0.76 \pm 0.21$ & $0.83 \pm 0.18$ & $0.95 \pm 0.19$ & $0.94 \pm 0.20$ \\
\hline
\end{tabular}

${ }^{1}$ For parathyroid hormone (PTH) challenge, PTH was administered intravenously at hour 1 .

${ }^{2}$ Mean \pm 1 SEM.

Table VI. Summary of data for patient $1(S R)^{1}$

\begin{tabular}{|c|c|c|}
\hline & \multicolumn{2}{|c|}{ State of rickets } \\
\hline & $\begin{array}{l}\text { Active, pre } \\
25-\mathrm{HCC}\end{array}$ & $\begin{array}{l}\text { Healed, post } \\
25-\mathrm{HCC}\end{array}$ \\
\hline \multicolumn{3}{|l|}{$\begin{array}{l}\text { Hourly excretion in urine of } \mathrm{mg} \text { phosphate/ } \\
\text { mg creatinine }\end{array}$} \\
\hline Control $^{2}$ & $3.92 \pm 0.08$ & $0.58 \pm 0.10$ \\
\hline PTH challenge ${ }^{2}$ & $4.04 \pm 0.06$ & $0.60 \pm 0.09$ \\
\hline \multicolumn{3}{|l|}{$\begin{array}{l}\text { Hourly excretion in urinc of nanomoles } \\
3^{\prime}, 5^{\prime}-\mathrm{AMP} / \mathrm{mg} \text { creatinine }\end{array}$} \\
\hline Control ${ }^{2}$ & $5.85 \pm 0.60$ & $3.19 \pm 0.30$ \\
\hline PTH challenge ${ }^{3}$ & 82.0 & 24.0 \\
\hline $\begin{array}{l}\Delta \text { Calcium (serum) above base line (in } \\
\mathrm{mg} / 100 \mathrm{ml} \text { ) after PTI- challenge }{ }^{3}\end{array}$ & 1.92 & 2.12 \\
\hline
\end{tabular}

ing standard experimental conditions adopted by several different laboratories, has been shown to be remarkably constant $[5,9,23,30,41,44]$. Moreover, the specificity of levels of $3^{\prime}, 5^{\prime}$-AMP in urine, as an exact indicator of PTH action on the kidney, has been strongly supported by the demonstration that very little exogenous PTH-induced excretion of $3^{\prime}, 5^{\prime}$-AMP (approximately $6 \%$ or less) is of extrarenal origin; and, during endogenous hyperparathyroidism, the nephrogenic contribution to basal $3^{\prime}, 5^{\prime}$-AMP excretion has been shown to be markedly increased [23].

The high basal levels of nanomoles $3^{\prime}, 5^{\prime}$-AMP/milligrams creatinine and milligrams phosphate/milligrams creatinine suggest, but do not prove, the existence of underlying hyperparathyroidism $[9,23,44]$ during a phase of this syndrome marked by hypocalcemia and hyperaminoaciduria. The metabolic significance for the observed increase in basal excretion of $3^{\prime}, 5^{\prime}$-AMP is incompletely understood, and will likely remain so until the physiologic role of $3^{\prime}, 5^{\prime}$-AMP is clarified. To date, it has been established that the action of PTH on bone and kidney involves the adenyl cyclase system and results in an increased concentration of intracellular
Table VII. Summary of data for patient $2(J M)^{1}$

\begin{tabular}{|c|c|c|}
\hline & \multicolumn{2}{|c|}{ State of rickets } \\
\hline & $\begin{array}{l}\text { Active, pre } \\
25-\mathrm{HCC}\end{array}$ & $\begin{array}{l}\text { Healed, post } \\
25-\mathrm{HCC}\end{array}$ \\
\hline \multicolumn{3}{|l|}{$\begin{array}{l}\text { Hourly cxcretion in urine of mg phosphate/ } \\
\text { mg creatininc }\end{array}$} \\
\hline Control $^{2}$ & $3.00 \pm 0.67$ & $0.76 \pm 0.21$ \\
\hline PTH challenge ${ }^{2}$ & $3.11 \pm 0.23$ & $0.83 \pm 0.18$ \\
\hline \multicolumn{3}{|l|}{$\begin{array}{l}\text { Hourly excretion in urine of nanomoles } \\
3^{\prime}, 5^{\prime}-\mathrm{AMP} / \mathrm{mg} \text { creatinine }\end{array}$} \\
\hline Control $^{2}$ & $6.10 \pm 0.70$ & $3.97 \pm 0.40$ \\
\hline PTH challenge ${ }^{3}$ & 82.0 & 19.0 \\
\hline $\begin{array}{l}\Delta \text { Calcium (serum) above base line (in } \\
\mathrm{mg} / 100 \mathrm{ml} \text { ) after PTH challenge }{ }^{3}\end{array}$ & 1.80 & 1.86 \\
\hline
\end{tabular}

Table VIII. Summary of data for patient $3(A R)^{1}$

\begin{tabular}{|c|c|c|}
\hline & \multicolumn{2}{|c|}{ State of rickets } \\
\hline & $\begin{array}{l}\text { Active, pre } \\
25-\mathrm{HCC}\end{array}$ & $\begin{array}{l}\text { Healed, post } \\
25 \text {-HCC }\end{array}$ \\
\hline \multicolumn{3}{|l|}{$\begin{array}{l}\text { Hourly excretion in urine of } \mathrm{mg} \text { phosphate/ } \\
\text { mg creatinine }\end{array}$} \\
\hline $\mathrm{Control}^{2}$ & $3.56 \pm 0.25$ & $0.95 \pm 0.19$ \\
\hline PTH challengc ${ }^{2}$ & $2.23 \pm 0.35$ & $0.94 \pm 0.20$ \\
\hline \multicolumn{3}{|l|}{$\begin{array}{l}\text { Hourly excretion in urine of nanomoles } \\
3^{\prime}, 5^{\prime}-\mathrm{AMP} / \mathrm{mg} \text { creatinine }\end{array}$} \\
\hline Control $^{2}$ & $5.62 \pm 0.69$ & $3.63 \pm 0$ \\
\hline PTH challenge ${ }^{3}$ & 99.0 & 31.0 \\
\hline $\begin{array}{l}\Delta \text { Calcium (serum) above base line (in } \\
\mathrm{mg} / 100 \mathrm{ml} \text { ) after PTH challenge }\end{array}$ & 1.86 & 1.80 \\
\hline
\end{tabular}

125-HCC: 25-hydroxycholccalciferol, P'TH : parathyroid hormone, 3', 5'-AMP: $3^{\prime}, 5^{\prime}$-adenosine monophosphate.

2 Mean values.

3 Maximum response.

3', 5'-AMP [39]. Nevertheless, very little data concerning specific metabolic systems subsequently affected by $3^{\prime}, 5^{\prime}$-AMP in renal and skeletal tissue have been reported. Needless to say, the intracellular actions of $3^{\prime}, 5^{\prime}$ AMP are currently under investigation in several laboratories [39].

The exaggerated responses to PTH most likely reflect administration of a larger dose of hormone rela- 


\begin{tabular}{|c|c|c|c|c|c|c|c|c|c|c|c|c|}
\hline & \multicolumn{6}{|c|}{ Active rickets } & \multicolumn{6}{|c|}{ Healed rickets ${ }^{1}$} \\
\hline & \multicolumn{3}{|c|}{ Patient 1} & \multicolumn{3}{|c|}{ Patient 2} & \multicolumn{3}{|c|}{ Patient1 } & \multicolumn{3}{|c|}{ Patient 2} \\
\hline & $\mathrm{Ca}$ & $P$ & $\mathrm{Mg}$ & $\mathrm{Ca}$ & $P$ & $\mathrm{Mg}$ & $\mathrm{Ca}$ & $P$ & $\mathrm{Mg}$ & $\mathrm{Ca}$ & $\mathrm{P}$ & $\mathrm{Mg}$ \\
\hline Dietary intake ${ }^{2}$ & 1250 & 1800 & 380 & 660 & 900 & 200 & 1350 & 1900 & 400 & 755 & 1100 & 225 \\
\hline \multicolumn{13}{|l|}{ Excretion $^{2}$} \\
\hline Urine & 2 & 180 & 8 & 3 & 93 & 6 & 201 & 1025 & 92 & 106 & 550 & 49 \\
\hline Stool & 1270 & 1605 & 400 & 660 & 825 & 260 & 800 & 475 & 200 & 453 & 330 & 110 \\
\hline \multicolumn{13}{|l|}{ Absorption 3} \\
\hline Patients & nil & 10 & nil & nil & 8 & nil & 40 & 74 & 50 & 43 & 70 & 51 \\
\hline Normal values 4 & 39 & 72 & 42 & 35 & 70 & 44 & & & & & & \\
\hline
\end{tabular}

${ }^{1}$ After treatment with 25-hydroxycholecalciferol.

${ }^{2}$ Mean, in $\mathrm{mg} / \mathrm{day}$.

${ }^{3}$ Percentage of intake.

${ }^{4}$ From Macy and Kelly [28].

tive to body weight. Similar responses have been recorded in two children with familial hypophosphatemia and have been ascribed to larger doses of PTH relative to body weight [5]. Adults with vitamin D-resistant rickets, it has been demonstrated, do respond appropriately to PTH challenge [5]. Nevertheless, the responses reported here and by others [23] indicate that relatively large doses of PTH can produce approximately a 30 -fold increase in $3^{\prime}, 5^{\prime}$-AMP excretion. The apparent dissociation in phosphate from $3^{\prime}, 5^{\prime}$ AMP excretion, therefore, does not seem to occur because of limited capacity of the renal adenyl cyclase system to generate $3^{\prime}, 5^{\prime}$-AMP. More likely, the limiting factor in the phosphaturic response is beyond the formation of $3^{\prime}, 5^{\prime}$-AMP. What it is that limits the responsiveness of a target cell to a hormone has never been clearly defined.

The metabolically active form of vitamin $\mathrm{D}$ is a requirement for effective $\mathrm{PTH}$ action on bone to mobilize calcium [37, 40]. Trummel and co-workers [45] have presented evidence that 25-HCC, once formed biologically from vitamin $\mathrm{D}$ in the liver, is the active metabolite effecting calcium mobilization from bone. Results of studies of the 2-day challenges with PTH tend to confirm their findings; i.e., the $\Delta$ serum calcium above base line during PTH administration was not significantly greater before than after treatment with 25-HCC. It would seem, therefore, that, while these patients were untreated, sufficient amounts of 25-HCC, or a different metabolite of vitamin D, were available to act jointly in effecting the calcium-mobilizing action of PTH.

The fact that these reported cases responded differently to DHT ( $A R$ and $S R$ never responded) would suggest that there is a partial block in the formation of 25-hydroxydihydrotachysterol from DHT. Nevertheless, results of studies of the 2-day challenges with PTH indicate that the calcium-mobilizing action of the hormone is intact, and, presumably, sufficient amounts of the 25-hydroxy metabolite are present to carry out this hormonal action. It follows, then, that this is a variable and incomplete block (see below). Moreover, these experimental results are not surprising in view of the hypothesis, expressed here and by others [4, 19], that impaired intestinal absorption of calcium (see below) is the cardinal event, which subsequently leads to hypocalcemia and hyperparathyroidism. Stated differently, we suggest that a proposed block in 25-hydroxylation is less significant clinically than a postulated block in 1-hydroxylation. These already complex interactions become even more intricate if, as recently suggested, PTH and calcitonin are actual regulators of 1,25-dihydroxycholecalciferol $\left(1,25-(\mathrm{OH})_{2} \mathrm{D}_{3}\right)$ synthesis as well as other vitamin $\mathrm{D}$ metabolites [8].

Despite the intactness of the calcium-mobilizing action of PTH with a vitamin D metabolite, presumably 25-HCC, the mineral contribution from increased bone resorption during hyperparathyroidism does not correct the observed hypocalcemia, although it helps to maintain serum levels of inorganic phosphate. In addition, with this degree of hyperparathyroiclism, a tubular defect in phosphate reabsorption, if present, is minimal and is not reflected by very low serum levels of inorganic phosphate. The observed hypocalcemia, then, is most likely secondary to a defect in small intestinal absorption. This defect results in larger net losses of calcium than of phosphorus, particularly when endogenous fecal excretion is included.

Small intestinal defects for absorption of calcium, 
phosphorus, and magnesium have been demonstrated in two patients during active rickets-a defect which is reversible after treatment with 25-HCC. Other aspects of small intestinal function were normal. Although intestinal biopsies were not performed, small bowel morphology in other patients with this disease has been previously reported to be normal [19]. The results of one mineral balance study in this disease, the only such study reported to date, were interpreted as a demonstration of impaired and selective intestinal absorption of calcium during active rickets [19]. However, the authors state that phosphorus absorption may have been slightly impaired, and they present evidence that phosphorus absorption was significantly increased after treatment with large doses of vitamin $\mathrm{D}_{3}$. Similar to the trend of results in the balance studies reported here, Hamilton and co-workers [19] reported that the excretion of phosphorus in urine increased from a pretreatment low of $63 \%$ to a posttreatment high of $98 \%$ (their data were expressed as percentage of intake). Further comparisons, however, are difficult because ( $(1)$ mineral excretion in urine during hourly intervals of a 24-hr period were not reported, and (2) the authors did not comment on the presence, or absence, of phosphaturia or hyperparathyroidism, or both, during the reported pretreatment balance periods when their patient was hypocalcemic [19].

The observed phosphaturia in consecutive urine collections limited to 4 -hr periods, during the specified time of day and experimental conditions, does not synchronize with the relatively small excretion of phosphate in urine over a complete 24-hr period-a period marked by severe impairment of intestinal phosphate absorption (Tables III and IX). Although the explanation of these data remains obscure, speculations concerning this sequence may be entertained.

In view of $(1)$ the recent suggestion that vitamin $\mathrm{D}$ metabolites may directly effect PTH secretion [51]; (2) the recent description of a new vitamin $\mathrm{D}$ metabolite, 21,25-dihydroxycholecalciferol, which is probably involved in tubular reabsorption of phosphate $[8,11]$; (3) new evidence to suggest that the formation of specific vitamin $\mathrm{D}$ metabolites may be directly controlled by calcitonin and PTH [8]; (4) the postulated, differential, and variable hydroxylating blocks in these children; and (5) likely presence of endogenous hyperparathyroidism in the active state of the disease, it may well be that a "steady state" of PTH secretion is not present during any clock-time period. We may have inadvertently found the "right" biologic time in defining a hormone-tissue-metabolic sequence (phosphate excretion in urine), involving, perhaps, great variability in PTH secretion over very short biologic time periods. Alternatively, there may be an as yet unnoticed effect of a large water load on phosphate excretion in this disorder. In any event, the apparent discrepancy between the acute experiments (Tables VI and VII) and the 24-hr balance studies (Table IX) with respect to phosphate excretion, although not germane to the conclusions drawn herein, does require further investigation. Consideration of these possibilities awaits more clinical research in this newly described syndrome, and investigation into the frequency and duration of secretory episodes of $\mathrm{PTH}$, similar to published studies of cortisol secretion [49]. In this regard, Parsons et al. [35] have recently demonstrated in vivo the very rapid and time-variable manifestations of PTH action.

Current evidence links calcium absorption to the presence of vitamin $\mathrm{D}_{3}$ or a metabolite thereof $[24,48]$. Phosphorus absorption is enhanced secondarily to that of calcium, and all three minerals, calcium, phosphorus, and magnesium, probably follow the same transport-pathway system in the gut $[2,32]$. Although this is disputed by some investigators [26, 50], PTH is not considered to be an absolute requirement for transport of these minerals across the intestine; to date, a direct action of PTH on mineral absorption has not been consistently demonstrated [36, 42]. Even if the presence of PTH was necessary for this expression of vitamin $\mathrm{D}$ action, there are sufficient data in this and other reports [4] to indicate underlying hyperparathyroidism in untreated patients. Moreover, availability of a vitamin $\mathrm{D}$-intestinally active metabolite appears to be the final limiting factor in these balance studies and clinical courses of these patients; after treatment with 25-HCC (1000 IU/24 hr for one patient and 5000 $\mathrm{IU} / 24 \mathrm{hr}$ for the other two), the absorptive defect has been completely reversed. The patient who responded to lower doses of $25-\mathrm{HCC}$, if given more time, may have ultimately responded to $500 \mathrm{IU}$, or less, of 25$\mathrm{HCC} / 24 \mathrm{hr}$. However, this very narrow dose range is characteristic of this syndrome. Nevertheless, it is clear that, at the very least, two of our patients responded only to large doses of 25-HCC. On the other hand, the presented data demonstrate the effective action of vitamin D (25-HCC) jointly with PTH in effecting the calcium-mobilizing action of PTH, both pre- and posttreatment. This finding fits in well with the proposed clinical chain of events-namely, intestinal malabsorption of calcium, hypocalcemia, hyperparathyroidism, and so on. 
In addition, these children responded dissimilarly to DHT_JM responded promptly to $2 \mathrm{mg} / 24 \mathrm{hr}$, whereas the two brothers never responded to very large doses (2-4 mg/24 hr for months) of DHT. To explain these responses, we suggest the possibility that variable and differential hydroxylating enzyme deficiences are present in the 25 and $l$ positions of the parent vitamin. These different therapeutic responses resemble the proposed coenzyme binding kinetics for pyridoxine-responsive genetic disease [31]. In the latter group of inborn errors of metabolism, and perhaps in vitamin D-dependent rickets as well, the possibility exists that the activities of the affected enzymes, although decreased, are not completely lacking. If, by therapeutic means, residual enzyme activities can be enhanced, appropriate metabolic responses may result. Thus, enzyme enhancement, to different degrees in these reported patients, may need to be extremely small to result in a physiologically significant event.

This report as well as others $[4,14,15]$ indicates the hereditary basis for this disease. We suggest that patients currently included in this syndrome may not necessarily all have the same autosomal recessive trait. Further, genetic heterogeneity, common to other inborn errors of metabolism, may well be present herein, indicating now the distinct possibility of more than one allele for vitamin D "dependence." Future evaluation of our postulate would be aided by the examination in vitro of the hydroxylating capacities of such patients' liver and kidney tissue, while they are on and off medication, and by treating such patients with I, 25-dihydroxycholecalciferol.

\section{Summary}

Three patients with vitamin $\mathrm{D}$-dependent rickets, two of them siblings, have been studied. The data presented on these patients demonstrate that: $(1)$ kidney is responsive to PTH, as measured by $3^{\prime}, 5^{\prime}$-AMP excretion, to an extent indicative of underlying hyperparathyroidism during active rickets; (2) PTH is effectively active on bone, to the same degree during both preand posttreatment with 25-HCC; and (3) impaired small intestinal absorption of calcium, phosphorus, and magnesium is reversible by $25-\mathrm{HCC}$ therapy. These results suggest that: (1) PTH is effective on kidney, both pre- and posttreatment; (2) sufficient amounts of 25-HCC or another metabolite are present to act jointly in effecting the action of PTH on bone, both pre- and postadministration of 25-HCC; and (3) unavailability of a vitamin $\mathrm{D}$-biologically active me- tabolite seems to impair mineral absorption by the small intestine during active rickets, which results in hypocalcemia and hyperparathyroidism. In view of the presented data and the dissimilar responses of patients to differing doses of $\mathrm{DHT}$ and $25-\mathrm{HCC}$, we speculate that the cardinal event in this disease is a relative failure in the biologic transformation of vitamin $\mathrm{D}$ to its active metabolites. Furthermore, we postulate that the metabolic block is differential and variable, and that it involves both the 25 and 1 hydroxylating positions of the parent vitamin.

\section{References and Notes}

1. Alcock, N. I., MAcIntyre, I., AND RAdDE, I.: The determination of magnesium in biological fluids and tissues by flame spectrophotometry. J. Clin. Pathol., (Lonclon), 13: 506 (1960).

2. AI_COCK, N., AND MAcINTYRE, I.: Interrelation of calcium and magnesium absorption. Clin. Sci. (London), 22: 185 (1962).

3. Arnaud, C., Rasmussen, H., and Anast, C.: Further studies on the interrelationship between parathyroid hormone and vitamin D. J. Clin. Invest., 45: 1955 (1966).

4. Arnaud, C., Maijer, R., Reade, T., Scriver, C. R., And Whelan, D. T.: Vitamin D dependency: an inherited postnatal syndrome with secondary hyperparathyroidism. Pediatrics, 46: $871(1970)$.

5. Aurbach, G. D., Marcus, R., Winickoff, R. N., Epstern, E. H., JR., AND NigRA, T. P.: Urinary excretion of $3^{\prime}, 5^{\prime}$-AMP in syndromes considered refractory to parathyroid hormonc. Metabolism, 19: 799 (1970).

6. Benson, J. A., Jr., Culver, P. J., Ragland, S., Jones, C. M., Drummery, G. D., and Bougas, E.: The D-xylose absorption test in malabsorption syndromes. New Engl. J. Med., 256: 335 (1957).

7. Bessey, O. A., Lowry, O. H., And Brock, M. J.: A method for the rapid determination of alkaline phosphatase. J. Biol. Chem., 164: 321 (1946).

8. Boyle, I. T., Gray, R. W., And Deluca, H. F.: Regulation by calcium of in vivo synthesis of 1,25-dihydroxycho!ccalciferol and 21, 25-dihydrocholccalciferol. Proc. Nat. Acad. Sci. U. S. A., 68: 2131 (197I).

9. Chase, L. R., Melson, G. L., and Aurbach, G. D.: Pseudohypoparathyroidism: defective excretion of $3^{\prime}, 5^{\prime}$-AMP in response to parathyroid hormone. J. Clin. Invest., 48: 1832 (1969).

10. Crakk, L. C., Jr., And Thompson, H. L.: Determination of creatine and creatinine. Anal. Chem., 21: 1218 (1949).

11. DeLuCA, H. F.: Personal communication.

12. Dent, C. E.: Discussion of the physiology and chemical disorders of the parathyroid glands. Proc. Roy. Soc. Med., 46: 291 (I953).

13. Dent, C. E., Fruedman, M., And Watson, L.: Hereditary pseudo-vitamin D deficiency rickets. J. Bone Joint Surg. B Brit. Vol., 50: 708 (I968).

14. Fanconi, A., And Prader, A.: Die hercelitare pseudomangelrachitis. Helv. Pacdiat. Acia, 24: 423 (1969).

15. Fanconi, A., and Prader, A.: Pseudo-vitamin D deficiency rickets. In: W. L. Burland and D. Barltrap: Mineral Metabolism in Pediatrics, p. 19. (Blackwell Scicntific, Oxford, 1969). 
16. Fiske, C. H., and Subbarow, Y.: The colorimetric determination of phosphorus. J. Biol. Chem., 66: 375 (1925).

17. Grose, J., ANid Scriver, C. R.: Parathyroid dependent phosphaturia and aminoaciduria in the vitamin $\mathrm{D}$ deficient rat. Amer. J. Physiol., 214: 370 (1968).

18. Hallick, R. B., and DeLuca, H. F.: 25-Hydroxydihydrotachysterol $_{3}$ : in vivo 25-hydroxylation of dihydrotachysterol ${ }_{3}$. Fed. Proc., 30: 407 (1971).

19. Hamilton, J. R., Harrison, J., Fraser, D., Radde, I., Morecki, R., AND PAunier, L.: The small intestine in vitamin $\mathrm{D}$ dependent rickets. Pediatrics, 45: 364 (1970).

20. Harrison, H. E.: Idiopathic hypoparathyroidism. Pediatrics, 17: 442 (1956).

21. Harrison, H.: The parathyroids. In: R. E. Cooke: The Biologic Basis of Pediatrics, p. 1136. (McGraw-Hill, New York, 1968).

22. Hawk, P. B., Oser, B. L., and Summerson, W. H.: Practical Physiological Chemistry. (McGraw-Hill, New York, 1954).

23. Kaminsky, N. I., Broadus, A. E., Hardman, J. G., Jones, D. J., Jr., Ball, J. H., Sutherland, E. W., and Liddle, G. W.: Effects of parathyroid hormone on plasma and urinary adenosine $3^{\prime}, 5^{\prime}$-monophosphate in man. J. Clin. Invest., 49: 2387 (1970).

24. Kimberg, D. V.: Effect of vitamin D and stcroid hormones on the active transport of calcium by the intestine. New Engl. J. Med., 280: 1396 (1969).

25. Law'son, D. E. M., Fraser, D. R., Kodicek, E., Morris, H. R., AND Williams, D. H.: Identification of 1,2̆-dihydrocholecalciferol, a new kidney hormone controlling calicum metabolism. Nature, 230: 228 (1971).

26. Lifschitz, F., Harrison, H. C., and Harrison, H. E.: Influence of parathyroid function upon the in vitro transport of calcium and phosphate by the rat intestine. Endocrinology, 84: $912(1969)$.

27. MACINTYRE, I.: The flame spectrophotometric determination of calcium in biological fluids and an isotopic analysis of the errors in the Kramer-Tisdall procedure. Biochem. J., 67: 164 (1957)

28. MACY, I. G., AND Kelly, H. J.: Chemical Anthropology. (University of Chicago Press, Chicago, 1957).

29. Matsuda, I., Sugai, M., and OHSAwa, T.: Laboratory findings in a child with pseudo-vitamin D deficiency rickets. Helv. Paediat. Acta, 24: 329 (1969).

30. Moskowitz, M. A., Winickoff, R. N., and Heinz, E. R.: Familial calcification of the basal ganglions. New Engl. J. Med., 285: 72 (1971).

31. Mudd, S. V.: Pvridoxine-responsive genetic disease. Fed. Proc., 30: $970(197 \mathrm{I})$.

32. Noble, H. M., and MATTY, A. J.: The effect of thyroxine on the movement of calcium and inorganic phosphate through the small intestine of the rat. J. Endocrinol., 37:111 (1967).

33. Norman, A. W., Myrtle, J. F., Nowicki, H. D., and Midgett, R. J.: Vitamin D: a cholecalciferol metabolite highly active in promoting intestinal calcium transport. Fed. Proc., 30: 407 (1971).

34. Omdahl, J. L., Tanaka, Y., and Deluca, H. F.: Mode of action of vitamin $\mathrm{D}_{3}$. Fed. Proc., 30: 407 (1971).

35. Parsons, J. A., Neer, R. M., and Potrs, J. T., Jr.: Initial fall of plasma calcium after intravenous injection of parathyroid hormone. Endocrinology, 89: 735 (1971).

36. Potts, J. T., JR., AND DeFros, L. J.: Parathyroid hormone, thyrocalcitonin, vitamin $\mathrm{D}$, bone and bone mineral metabolism. In: P. K. Bondy and L. E. Rosenberg: Diseases of Metabolism, p. 970. (W. B. Saunders, Philadelphia, 1969).

37. Raisz, L. G.: Physiologic and pharmacologic regulation of bone resorption. New Engl. J. Med., 282: 209 (1970).

38. Ramsax, W. N. M.: Plasma iron. In: H. Sobotka and C. P. Stewart: Advances in Clinical Chemistry. (Academic Press, London, 1958).

39. Rasmussen, H.: Ionic and hormonal control of calcium homeostasis. Amer. J. Med., 50: 567 (1971).

40. Rasmussen, H., and Deluca, H. F.: Calcium homeostasis. Ergeb. Physiol., 53: 108 (1968).

41. Rosen, J. F., ANd Haymovits, A. H.: Liver lysosomes in congenital osteopetrosis: a study of lysosomal function, parathyroid hormone, calcitonin, and $3^{\prime}, 5^{\prime}$-AMP. J. Pediat. (In press).

42. SCHACTER, D.: Vitamin D and the active transport of calcium by the small intestine. In: Transfer of Calcium and Strontium Across Biological Membranes, p. 197. Proceedings of conference held at Cornell University, Ithaca, N. Y., May, 1962. (Academic Press, New York and London, 1963).

43. Stoop, J. W., Schrangen, M. J. C., and Tiddens, H. A. W.: Pseudo vitamin D deficiency rickets. Acta Paediat. Scand., 56: $607(1967)$.

44. Taylor, A. L., Davis, B. B., Pawlson, G., Josimovich, J. B., AND MrNTz, D. H.: Factors influencing the urinary excretion of $3^{\prime}, 5^{\prime}$-adenosine monophosphate in humans. J. Clin. Endocrinol. Metab., 30: 316 (1970).

45. Trummel, C. L., Raisz, L. G., Blunt, J. W., and Deluca, H. F.: 25-Hydroxycholecalciferol: stimulation of bone resorption in tissue culture. Science, 163: 1450 (1969).

46. U. S. Pharmacopeia XV, 14th Revision. (Mack, Easton, Md., 1955).

47. Vandekamer, J. H., Tfaibokkel Huinick, H., and Weijers, H. A.: Rapid method for the determination of fat in feces. J. Biol. Chem., 177: 347 (1969).

48. Wasserman, R. H., Taylor, A. N., and Kallfelz, F. A.: Vita$\min \mathrm{D}$ and transfer of plasma calcium to intestinal lumen in chicks and rats. Amer. J. Physiol., 211: 419 (1966).

49. Weitzman, E. D., Fukushima, D., Nogeire, C., Roffwarg, H., Gallagher, T. F., and Hellman, L.: Twenty-four hour pattern of the cpisodic secretion of cortisol in normal subjects. J. Clin. Endocrinol. Metab., 33: 14 (1971).

50. Wills, M. R., Worstman, J., Pak, C. Y. C., aNd Bartter, F. C.: The role of parathyroid hormone in the gastrointestiual absorption of calcium. Clin. Sci. (London), 39: 89 (1970).

51. Woodhouse, N. J. Y., Doyle, F. H., ANd Joplin, G. F.: Vitamin $\mathrm{D}$ deficiency and primary hyperparathyroidism. Lancet, ii: 283 (1971).

52. Eli Lilly and Company, Indianapolis, Ind.

53. Supplied by Professor H. F. DeLuca through the courtesy of the Upjohn and Philips-Duphar Companies.

54. Wisconsin Alumni Research Foundation, Madison, Wisconsin.

55. Quantitative measurement of 24-hr urinary excretion of amino acids was performed by Professor H. Nitowsky, The Albert Einstein College of Medicine, on a Beckman 120c amino acid analyzer, according to Spackman, D. H., Stein, W. H., and Moore, S.: Anal. Chem., 30: 1190 (1958).

56. We want to acknowledge the constructive advice and rarm 
encouragement offered by Professor H. F. DeLuca during various stages of this study. In addition, the expert technical assistance of Miss Carol Lagala is gratefully acknowledged.

57. Informed consent for any procedures was obtained in accordance with the provisions set forth in the Declaration of Helsinki.

58. Presented in part at the 55th Annual Meeting of The Federa- tion of American Societies for Experimental Biology, Chicago, Ill., April 14, 1971.

59. Requests for reprints should be addressed to: JoHn F. Rosen, M.D., Department of Pediatrics, Montefiore Hospital and Medical Center and The Albert Einstein College of Medicine, 111 East 210th Street, New York, N. Y. 10467 (USA).

60. Accepted for publication January 5, 1972. 